\section{Fatores associados à infecção/colonização por Streptococcus pneumoniae resistente à penicilina}

Com a finalidade de descrever as características dos pacientes com infecção ou colonização por Streptococcus pneumoniae atendidos nos Hospital das Clínicas da FMUSP, assim como as características das cepas (susceptibilidade antimicrobiana e sorotipos); e avaliar a existência de fatores associados à resistência a penicilina, foi realizado um estudo transversal.

Todos os pacientes com cultura positiva para S. pneumoniae no período de julho de 1991 a dezembro de 1992 e todo o ano de 1994 foram avaliados, desde que a cepa permanecesse viável para teste com penicilina. Foram obtidos dados demográficos, clínicos e de susceptibilidade antimicrobiana e sorotipos.

Foram estudados 165 pacientes, sendo 26 considerados portadores e 139 infectados. Foram $92(55,8 \%)$ do sexo masculino, 107 (64,8\%) adultos e $58(35,2 \%)$ crianças. A letalidade total entre os infectados foi $25,2 \%$, sendo $33 \%$ entre os adultos. Os diagnósticos infecciosos mais freqüentes foram: pneumonias $(43,9 \%)$; infecções do Sistema Nervoso Central (18,7\%); e infecções abdominais e pélvicas $(11,5 \%)$. Havia uma ou mais condições de base presentes em $75,8 \%$ dos pacientes. Houve 128 cepas sensíveis (S) à penicilina $(77,6 \%) ; 21,8 \%$ de cepas intermediárias (I); e uma cepa resistente (R). Em relação a tetraciclina, houve $63,4 \%$ de cepas $R ; 7,3 \%$ de I; e $29,3 \%$ de cepas S. Para cotrimoxazol houve $59,3 \%$ de cepas S; $18,7 \%$ de I; e $22 \%$ de R. Para a eritromicina houve $97,6 \%$ de cepas S; para a rifampicina houve $99,2 \%$ de cepas $S$. Para vancomicina, cloranfenicol e cefotaxima não foi observada resistência.

Houve 36 sorotipos diferentes entre as 162 amostras sorotipadas, sendo as mais frequentes: 14; 23F; 9V; 3; 5; 6B; 6A; 4; e 19F. Dentre o total das amostras $77,2 \%$ foram de sorotipos incluídos na vacina anti-pneumocócica 23-valente. Considerando os sorotipos contra os quais pode haver proteção cruzada, houve $87,6 \%$ de

\section{Factors associated with infection/colonization by penicillin-resistant Streptococcus pneumoniae}

The object of this study was to describe: the characteristics of patients attended at Hospital das Clínicas da FMUSP infected or colonized by S. pneumoniae; to determine antimicrobial susceptibility and serotypes of these strains; and to evaluate the presence of factors associated with resistance to penicillin.

All patients with a positive culture for S. pneumoniae from July 1991 to December 1992 and during 1994, were included, as long as the strain remained viable for penicillin testing. Demographic and clinical data, antimicrobial susceptibility patterns and serotypes were obtained.

One hundred sixty five patients were studied, 26 were considered carriers and 139 had pneumococcal infections. 92 (55.8\%) were male, $107(64.8 \%)$ were adults and 58 were children. Total mortality among infected patients was $25.2 \%$, and among adults it reached $33 \%$. The most common infections were: pneumonia $(43.9 \%)$; central nervous system infections $(18.7 \%)$; and abdominal and pelvic infections $(11.5 \%)$. At least one underlying condition was present in $75.8 \%$ of the patients. There were 128 strains susceptible (S) to penicillin $(77.6 \%)$; $21.8 \%$ intermediate (I) strains; and one resistant (R) strain. To tetracycline $63.4 \%$ were $\mathrm{R} ; 7.3 \%$ were I; and $29.3 \%$ were S. To cotrimoxazol there were $59.3 \%$ of S strains; $18.7 \%$ I; and $22 \%$ R. $97.6 \%$ of strains were $S$ to erythromycin; and $99.2 \%$ were $S$ to rifampin. No resistance was observed to vancomycin, chloramphenicol or cefotaxime.

There were 36 different serotypes. The most common were: 14 ; 23F; 9V; 3; 5; 6B; 6A; 4; and $19 \mathrm{~F} .77 .2 \%$ of the strains belonged to serotypes included in the 23-valent anti-pneumococcal vaccine. Considering the serotypes that may be affected by cross protection $87.6 \%$ of the strains were "vaccinal". Among penicillin-resistant strains there were 9 different serotypes: $14 ; 23 \mathrm{~F} ; 6 \mathrm{~B}$;

Recebido para publicação em 06/04/98. 
amostras "vacinais". Dentre as amostras resistentes à penicilina houve apenas nove sorotipos: 14; 23F; 6B; 19A; 11A; 19F; 4; 6A; e 7B, sendo $94,7 \%$ das cepas "vacinais".

Comparando as cepas de Streptococcus pneumoniae susceptíveis e não-susceptíveis (resistentes) à penicilina, encontramos pela análise univariada apenas dois fatores associados à resistência: faixa etária (até três anos) e a menor presença de bacteremia. Esses fatores se mantiveram significativos na análise multivariada.

A presença de Streptococcus pneumoniae em crianças até três anos de idade deve estar associada à suspeita de resistência à penicilina, e a terapêutica empírica de infecções graves deve levar em conta essa suspeita. A resistência foi associada a uma freqüência menor de bacteremias sugerindo uma menor invasividade dessas cepas. Devido à alta letalidade da doença pneumocócica, à alta incidência de resistência à penicilina, e à boa cobertura vacinal em relação às amostras isoladas no nosso meio, acreditamos que o uso da vacinação é muito importante nos grupos de risco para a doença.
$19 \mathrm{~A} ; 11 \mathrm{~A} ; 19 \mathrm{~F} ; 4 ; 6 \mathrm{~A}$; and $7 \mathrm{~B}$, and $94.7 \%$ of these strains were "vaccinal".

Comparing cases of penicillin-susceptible and non-susceptible (resistant) strains univariate analysis led to 2 factors significantly associated with resistance: - age (3 years or less) and a lower incidence of bacteremia. The multivariate analysis confirmed these results.

When S. pneumoniae is suspected in a child of up to 3 years, the possibility of penicillinresistance must guide empirical therapy, until results of cultures and antimicrobial susceptibility tests are available. Penicillin-resistance was associated with a lower frequency of bacteremia, suggesting that these strains are less invasive. Because of high mortality, high levels of resistance and the high coverage afforded by the vaccine in our study, vaccination should be used in all the high risk groups for pneumococcal disease.

\section{Anna Sara Shafferman Levin}

Tese apresentada à Faculdade de Medicina da Universidade de São Paulo para a obtenção do Título de Doutor em Medicina.

São Paulo, SP, Brasil, 1996. 